\title{
Diagnosis and Management of Heterotopic Pregnancy: A Case Report
}

\author{
Harnovin Kuanda ${ }^{1}$, Muhamad Husen Ali², Rommy Andika Kurniawan ${ }^{2}$ \\ ${ }^{1}$ Puskesmas Waigete, Kabupaten Sikka, Flores, NTT \\ ${ }^{2}$ SMF Obstetri dan Ginekologi, RSUD Dr. T.C. Hillers Maumere, Kabupaten Sikka, Flores, \\ NTT
}

Korespondensi: Harnovin Kuanada, Email: novinkuanda@gmail.com

\begin{abstract}
Abstrak
Background: Heterotopic pregnancy is a rare case of pregnancy. The incident is estimated to be 1:30000 to spontaneus pregnancy. Heterotopic pregnancy is a life threatening condition to maternal and intrauterine fetus.

Case Report:A 36 years old woman came with over 1 month history of amenorrhea, after being examined, her gestational age was 9-10 weeks. On $28^{\text {th }}$ February 2018 patient came to PHC due to lower abdominal pain and vaginal bleeding. Ectopic pregnancy was revealed then laparotomy was performed. Then, patient came back and complained of enlarged abdomen since the laparotomy, ultrasonography examination showed intrauterine fetus. At 35 weeks gestational age, patient was undergoing cesarean section due to fetal distress.

Discussion:Heterotopic pregnancy are both intrauterine and ectopic pregnancy that occur at the same time. Heterotopic pregnancy often hardly detect because of unspecific symptoms. In this case it also found difficulty in diagnosing heterotopic pregnancy, the patient was only diagnosed as ruptured ectopic pregnancy.

Conclusion:Heterotopic pregnancy has a high mortality rate if the diagnosis and treatment is not done well. Ultrasonography (USG) examination has an important role in order to help diagnosing in remote area.
\end{abstract}

Key words : Heterotopic pregnancy, USG, Diagnose, Treatment

\section{Diagnosis dan Tatalaksana Kehamilan Heterotopik: Sebuah Laporan Kasus}

\begin{abstract}
Abstrak
Latar belakang:Kehamilan Heterotopik adalah kehamilan yang sangat jarang terjadi, angka kejadiannya sekitar 1:30000 dibandingkan dengan kehamilan spontan. Kehamilan Heterotopik seringkali menyebabkan komplikasi yang dapat mengancam jiwa ibu dan janin.

Laporan Kasus:Wanita usia 36 tahun datang dengan keluhan Amenorea lebih dari 1 bulan, setelah di periksa pasien dinyatakan hamil dengan usia kehamilan 9-10 minggu. Pada 28 februari 2018, pasien datang ke puskesmas dengan keluhan nyeri perut bawah dan keluar darah dari jalan lahir, kemudian pasien di rujuk ke Rumah Sakit. Pasien didiagnosis dengan kehamilan ektopik dan dilakukan laparotomi. Kemudian pasien kontrol dan mengeluh perut bertambah besar pascaoperasi, dari pemeriksaan ultrasonographi didapatkan adanya janin intrauterin. Pada usia kehamilan 35 minggu dilakukan operasi caesar dikarenakan gawat janin.

Diskusi:Kehamilan Heterotopik adalah kehamilan intrauterin dan kehamilan ektopik yang terjadi pada waktu yang bersamaan. Kehamilan heterotopik seringkali sulit dideteksi dikarenakan gejala yang tidak spesifik. Pada kasus ini juga ditemukan kesulitan dalam mendiagnosa kehamilan heterotopik-

Kesimpulan:Kehamilan heterotopik memiliki angka mortalitas yang tinggi jika diagnosis dan tatalaksana yang dilakukan tidak baik. USG berperan penting dalam membantu penegakkan diagnosis di daerah terpencil.
\end{abstract}

Kata kunci: Kehamilan Heterotopik; USG; Diagnosis; Tatalaksana 


\section{Backgrounds}

Heterotopic pregnancy is pregnancy characterized by coexistence of an ectopic pregnancy and an intrauterine pregnancy in the same patient. ${ }^{1}$ The first case was found in 1708 by Duvernet, at that time diagnosis was established during autopsy. ${ }^{2}$ Heterotopic is very rare case but it is also potentially lifethreatening. It can cause ruptured ectopic pregnancy, hypovolemic shock, or even loss of life. ${ }^{3}$ Early and accurate diagnosis of heterotopic can prevent all potential life threatening risk.

\section{Objective}

To increase awareness in daily clinical practice to achive early diagnosis and proper management of heterotopic pregnancy in order to avoid potential life threatening risks especially in the rural area.

\section{Case Report}

A 36 years old woman came to primary health center on $5^{\text {th }}$ February 2018 that she complained no menstruation for more than 1 month. After being examined, the patient was declared pregnant. The patient said that her first day of last menstruation period was $29^{\text {th }}$ of December 2017. On $28^{\text {th }}$ of February 2018 , patient came to primary health center due to severe abdominal pain and vaginal bleeding. The patient was compos mentis, her vital sign were blood pressure $70 / 50 \mathrm{mmHg}$, pulse rate $100 \mathrm{bpm}$, respiratory rate $21 \mathrm{bpm}$; and temperature $36,4^{\circ} \mathrm{C}$. Pelvic examination revealed that there was no cervical dilatation, the portio was firm, and blood clot was found. Then, $1000 \mathrm{cc}$ of ringer lactate were given as resuscitation and patient was referred to the hospital afterwards.

Patient was compos mentis at the hospital. It was revealed that blood pressure was 90/60 mmHg, Pulse rate was $100 \mathrm{bpm}$, respiratory rate was $21 \mathrm{bpm}$, temperature was $36,9^{\circ} \mathrm{C}$. Physical examination showed that subconjungtival anemia $(+)$, cold extrimities $(+)$. On abdominal examination, uterine fundus was not palpable, pelvic examination revealed that there was no cervical dilatation, and slinger pain was positive. Her hemoglobin level was $8,7 \mathrm{~g} / \mathrm{dL}$, leucocytes $13.37 \times 10^{3} /$

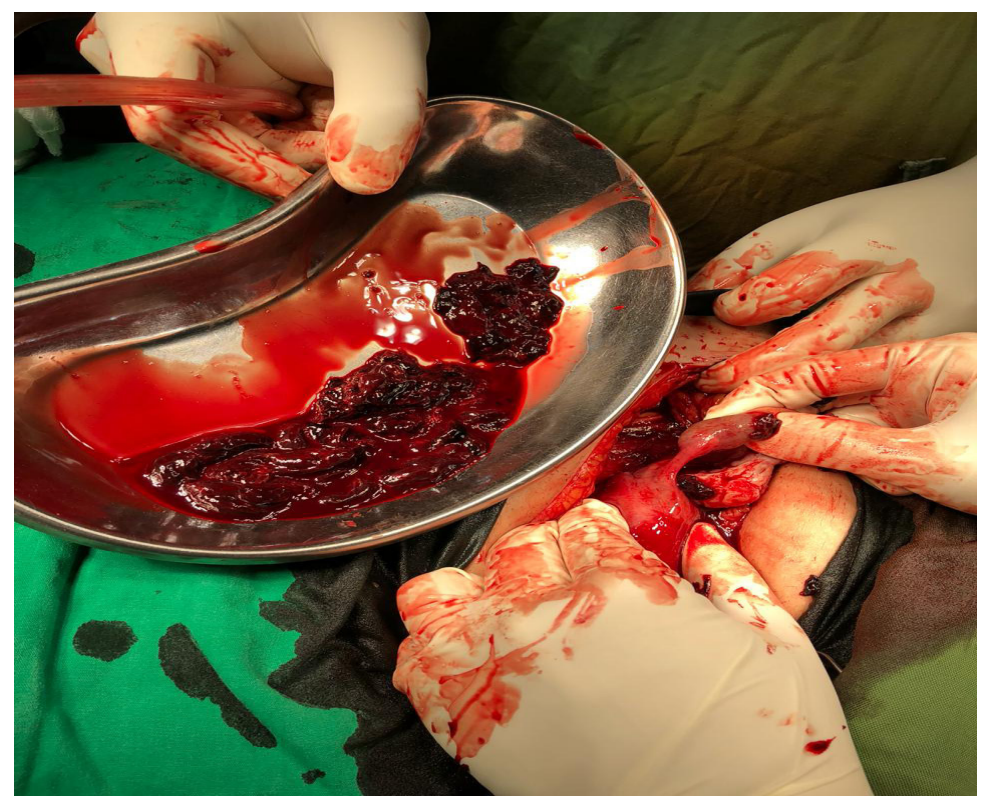

(a) 


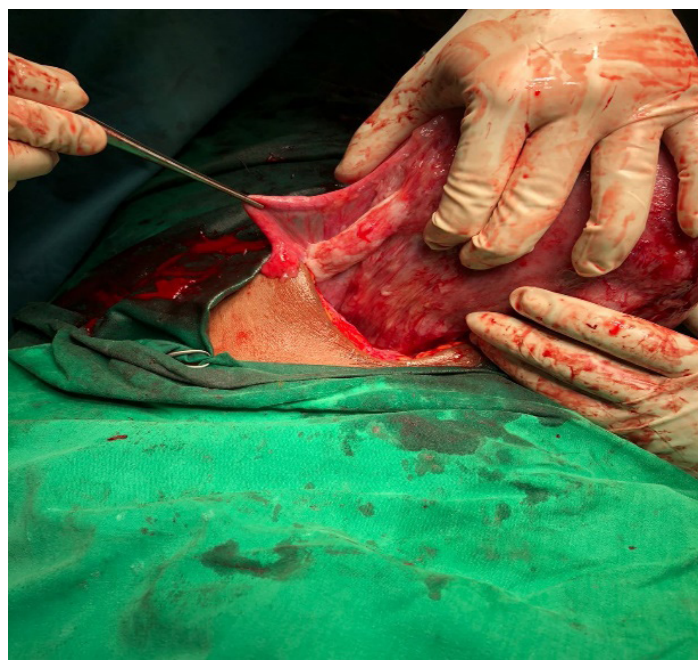

(b)

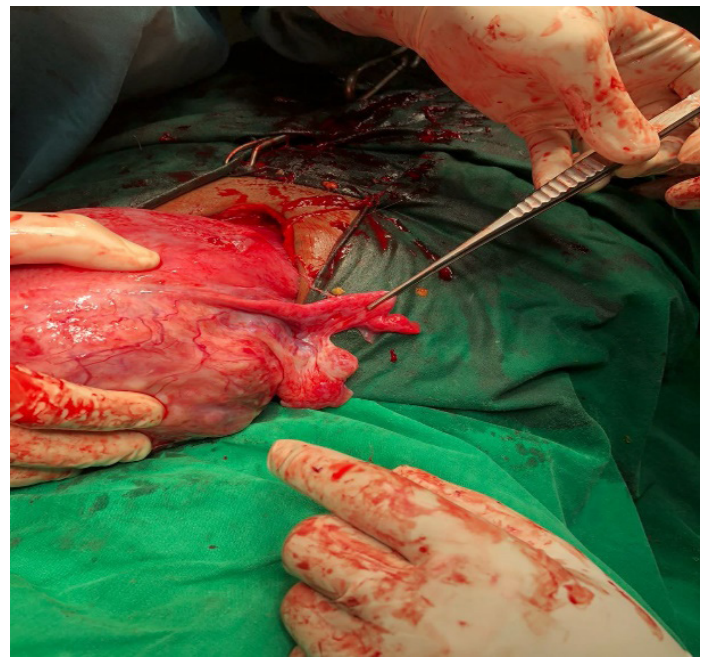

(c)

Figure 1. (a) Intraoperative Situation, showing the presence of coagulum in abdomen cavity. (b) showing the right Tuba Falopy, fimbrae, and ovarium in normal condition. (c) showing the left Tuba Falopy, fimbrae, and ovarium in normal condition.

$\mu \mathrm{L}$. On obstetric ultrasound examination, there was free fluids, intraabdominal fetus. It was also seen uterine myoma with size of $4 \mathrm{~cm}$ $\mathrm{x} 4 \mathrm{~cm}$, therefore the patient was diagnosed with coexisting ectopic pregnancy. On $1^{\text {st }}$ of March 2018, laparotomy was performed revealing the fetus adhered with the omentum. The Tuba falopy, fimbrae and ovarium were normal, the fetus was evacuated and sent to anatomical pathology department However, the patient denied to be examined due to limited costs. After hospitalized for 2 days, she was allowed to go home.

On $3^{\text {rd }}$ April 2018, patient controlled to the Obstetrician and complained that her abdomen was enlarged after the laparotomy. On Physical examination, it was revealed the fundal height was $16 \mathrm{~cm}$ and ultrasound examination showed that intrauterine fetus with crown rump lenght $9.48 \mathrm{~cm}$, fetal heart beat + , and estimated gestational was 15 weeks 2 days. The estimated labor was on 23th September 2018. Therefore, she was diagnosed with heterotopic pregnancy (intrauterine with coexisting ectopic pregnancy history) with uterine myoma.

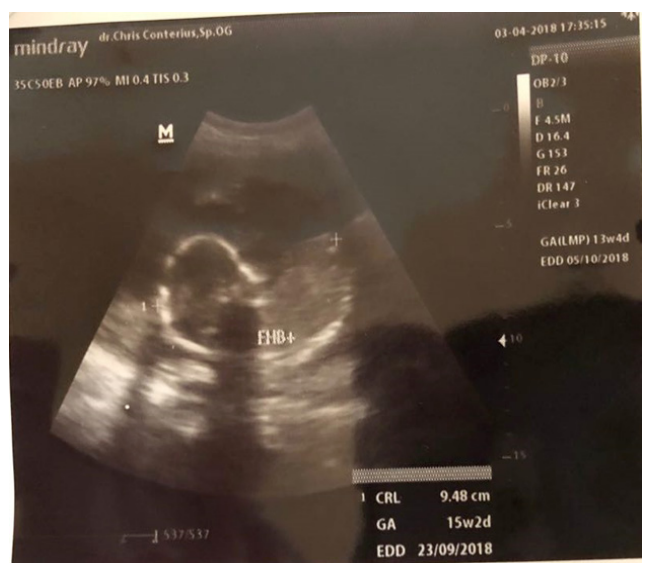

Figure 2. Transabdominal Ultrasonography that showing intrauterin fetus with Fetal Heart beat and Gestational Ages 15 weeks 2 days on $3^{\text {rd }}$ April 2018

Patient underwent routine antenatal care in PHC and hospital. On $3^{\text {rd }}$ July 2018, patient controlled to obstetricians and ultrasound examination showed biparietal diameter 7.64 $\mathrm{cm}$, abdominal circumferencial $25.82 \mathrm{~cm}$, estimate fetal weight 1629 grams, placenta was located in posterior fundal which is placenta grade II, enough amniotic fluid, and it showed 30 weeks and 4 days of pregnancy. The uterine myoma was $6 \mathrm{~cm} \times 6 \mathrm{~cm}$ and the patient was advised to undergo an elective 
caesarean section within 37-38 weeks of pregnancy.

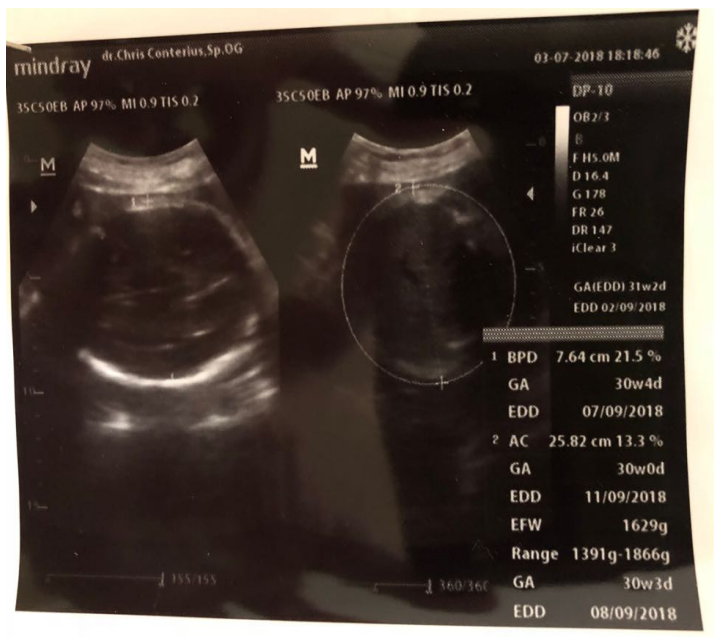

Figure 3. Transabdominal ultrasonography showing the fetus growing intrauteri with Gestational Ages 30 weeks and Estimated Fetal Weight 1629 gr

On $29^{\text {th }}$ August 2018, patient came to the PHC and the the gestational age was 35 weeks, she complained of labor pain. Patient was referred to hospital with $1^{\text {st }}$ stage of labor, breech presentation, with coexisting ectopic pregnancy history, and uterine myoma. The blood pressure was $120 / 80 \mathrm{mmHg}$, pulse rate was $80 \mathrm{bpm}$, respiratory rate was 18 $\mathrm{bpm}$ and temperature was $36,5^{\circ} \mathrm{C}$. Fundal height was $36 \mathrm{~cm}$ and fetal heart rate was 165 bpm. Vaginal examination showed that cervical dilatation was $2 \mathrm{~cm}$, thick and soft portio, intact amniotic membrane, as well as palpable facial part with mentum posterior denominator. Laboratory analysis showed hemoglobin concentration of $8.0 \mathrm{~g} /$ dl. Nonstress test revealed the baseline rate 160 bpm, acceleration -, deceleration+, variability 2-4 bpm lost of shoulder ring + . Then Fetal distress was stated and caesarian section was performed. A female infant was born with birth weight 2300 gram, accompanied by 5 times tight nuchal cord entanglement. Apgar score was 8-9 with meconial amniotic fluid. Both adnexa were normal and intramural uterine myoma was $6 \mathrm{~cm} \times 6 \mathrm{~cm}$.

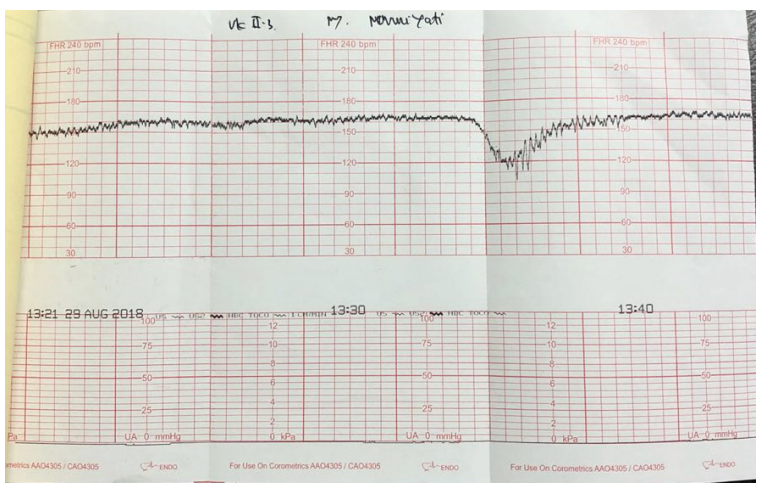

Figure 4. The NST showing baseline rate $160 \mathrm{bpm}$, acceleration -, deceleration + , variability 2-4 bpm, lost of shoulder ring +

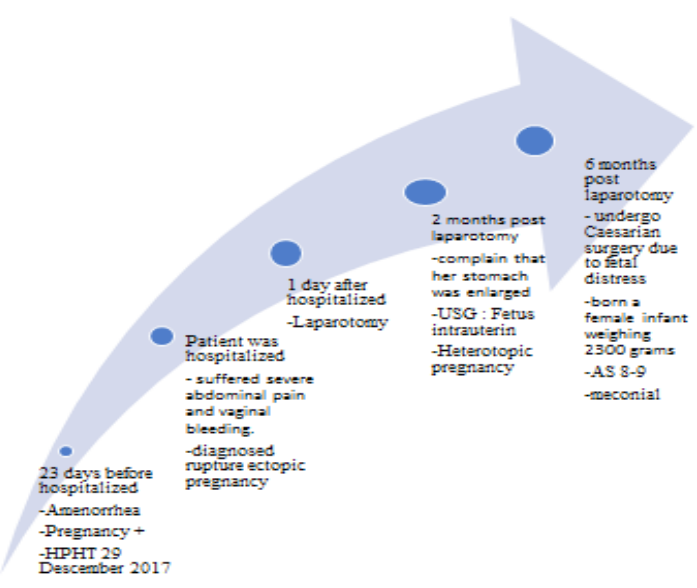

Figure 5. Time table that describe about the case

\section{Discussion}

Heterotopic pregnancy is a unique condition that can be diagnosed by discovering intrauterine and extrauterine pregnancies during the same gestational period.

Spontaneus heterotopic pregnancy is a rare disorder with incidence of 1:30000 in spontaneus pregnancy. However, the incidence increases with the presence of assited reproductive technology. The incidence of this case increased by $0.09 \%$ $1.00 \%$, or else 1:100-1:7000 pregnancies in women who received assited reproductive technology. ${ }^{3,4}$ Risk factors such as sexual 
transmited infections, tubal surgery, and also ovulation induction with gonadotropin and clomiphene citrate could also increase the incidence of heterotopic pregnancy. ${ }^{5,6}$

This confirms that the significance of detection of risk in pregnant woman in order to increase awareness of diagnosing this rare condition. In this written case, there were no risk factors, in other words it is concluded that this case is a spontaneus HP, which is a very rare condition. The most common ectopic implantation site on HP is the oviduct $(93,9)$, and it is less common in ovary $(6 \%) .{ }^{2}$ On the other hand implantation can also occur in the cervic, cornu, or in the abdomen. ${ }^{1}$ In this case implantation occur in intrauterine and intraabdomen, where the fetus is embedded in the omentum so that the right and the left adnexa are still in normal condition.

Clinically, HP has a clasical triad which are amenorrhea, vaginal bleeding, and pelvic pain. While more than $50 \%$ of HP cases are asymptomatic, abdominal pain, adnexal mass, peritoneal irritation, and also an enlarged uterus could also be the manifestation of heterotopic pregnancy. ${ }^{6,7}$ Early and proper diagnosis of heterotopic pregnancy could significantly reduce the patient's mortality rate. ${ }^{7}$ This becomes a challenging problem for Obstetricians in achieving an accurate diagnosis by facing obscure clinical symptoms from patients, in order to reduce the mortality rate. In this case, the patient experienced severe pain in the lower abdomen accompanied by vaginal bleeding. Transabdominal ultrasound showed a freefluid in the abdominal cavity, extrauterine fetus, and also a uterine myoma with dimension of $4 \times 4 \mathrm{~cm}$. It was initially thought to be a ruptured ectopic pregnancy due to the absence of an intrauterine fetus. This missing image of intrauterine fetus could probably occur because it was blocked by extrauterine fetus and uterine myoma. Ultrasonography is actually recommended to be carried out transvaginally, with a sensitivity of $74-84 \%$ and specificity of $84-99.9 \%{ }^{4}$

However, because it was presented with emergency condition, such as severe abdominal pain and heavy vaginal bleeding, it was decided to do transabdominal ultrasound rather than transvaginal ultrasound. This might be one of the factors that lead to the unidentified intrauterine fetus. In any case, USG is an operator dependent technology. ${ }^{4}$

Some literatures shows that out of 192 HP cases, only one-third of the cases that were identified using USG pre-operatively. ${ }^{4}$ In addition to USG, MRI is very helpful in diagnosing HP, but this modality could only be found in advanced-resource areas. ${ }^{6}$

Heterotopic Pregnancy can be treated in surgical or medical procedure. It depends on the hemodynamic status of the patient and the expertise of the physician. ${ }^{7}$ If the ectopic pregnancy was detected early and unruptured, treatment options include transabdominal sonographic guided aspiration of ectopic gestational embryo with or without embryo killing drug. It's minimally invasive and has been performed as treatment modality of Ectopic Pregnancy for years.

The difficulty of this treatment in Heterotopic Pregnancy's management depends on the location of the ectopic gestational sac. It should be done only when the ectopic gestational sac is clearly visualized. Also, potassium chloride and hyperosmolar glucose can be used as embryo killing drugs in management of HP,while methotrexate should be avoided because of its teratogenic effects on the viable IUP. ${ }^{7,3}$ Surgery is done in the case of an ruptured ectopic and the intrauterine pregnancy is expected to continue normally ${ }^{7}$. The gold standard in diagnosis of the heterotopic pregnancy is laparoscopy. It allows to clearly determine the size of the uterus, view the EP, assess the state of the trunk, quantify the hemoperitoneum, and achieve therapeutic procedure. ${ }^{6}$ Exploratory laparotomy is appropriate when a ruptured ectopic pregnancy is associated with severe 
intra abdominal haemorrhage. ${ }^{7}$ In this case, laparoscopic procedure was not done because of the absence of equipment and the unstable hemodynamics of patient. It was decided to manage by laparotomy. The tuba and ovary was still intact so that its possible for the patient to get pregnant again later. As more and more infertile couples turn to assisted reproductive technique, the incidence of heterotopic pregnancy has expectedly increased from $1.9 \%$ to $2.9 \%$. If the patient has had history of previous pelvic inflammatory disease or tubal pathology, there will be an obvious increase in rate of occurence of ectopic pregnancies ${ }^{8}$. Therefore, it can be concluded that heterotopic pregnancy can still occur again if patient has risk factors for ectopic pregnancy.

\section{Conclusion}

Heterotopic pregnancy is a very rare entity with high mortality rate because of its unstable hemodynamics due to severe bleeding from ruptured ectopic pregnancy. Early diagnosis and appropriate management could significantly reduce the life-threatening risk of the pregnant women and intrauterine fetus. Ultrasonography has a major role in diagnosing HP in limited-resource areas. Frequently, there is no treatment such as laparoscopy, potassium chloride and hyperosmolar glucose procedure in rural areas. Therefore if rupture has occurred in ectopic pregnancy and the patient's hemodynamic is unstable, laparotomy is the most appropriate therapeutic choice. The multidisciplinary approaches are also very important in reducing maternal morbidity and mortality.

\section{Reference}

1. Bagchi S, Aggrwal A, Gupta AK, Aggarwal AK, et al (2015). "Heterotopic Pregnancy with an Intrauterine Twin Gestation and Ruptured Tubal Pregnancy: An Unusual Presentation". J Fetal Med. 2
: 179-181.

2. Skrajna A, Cendrowski K, Alkhalayla H,Sawicki W (2012). "Heterotopic Pregnancy :A Case Report. Heterotopic Pregnancy A case report". Journal of Ultrasonography. $12: 342-348$.

3. Li JB, Kong LZ, Yang JB, Niu G, et al (2016). "Management of Heterotopic Pregnancy : Experience From 1 Tertiary Medical Center". Md-Journal. 95(5) : 1-7.

4. Kwok TC, Morgan G (2012). "Think Heterotopic: A case Report of Heterotopic Pregnancy Detected on Thorough Ultrasonography“. J Med Cases. 3(5) : 326-328.

5. Sunita V, Ramya M, Shruthi T, Sangeetha G (2016). "Heterotopic Pregnancy: Challenges in Diagnosis and Management". Open Journal of Obstetrics and Gynecology. $6: 445-450$.

6. Mohamed D, Driss M, Jaouad K (2017). "Advanced Heterotopic Pregnancy: A Case Report". Journal of Gynecology and Obstetrics. 5(1) : 9-19.

7. Saha E, Das J, Moniruzzaman M, Bacher CR (2016). "Laparoscopyic Management of Tubal Ectopic of Heterotopic Pregnancy". Journal of Bangladesh College of Physicians and Surgeon. 34(4) : 218-221.

8. Baxi A, Kaushal M, Karmalkar HK, Sahu P, et al (2010). "Successful expectant management of tubal heterotopic pregnancy". Journal of Human Reproductive Sciences. 3(2) : 108-110. 